\title{
IDENTIFIKASI TELUR Ascaris lumbricoides PADA FESES ANAK SEKOLAH DASAR KELAS 5 DAN 6 DI YAYASAN DINAMIKA INDONESIA, BANTAR GEBANG
}

\author{
Lili Rosmalia $^{1^{*}}$, Intan Kurniawati Pramitaningrum ${ }^{2}$ \\ 1. Program Studi DIII Teknologi Laboratorium Medik, STIKes Mitra Keluarga, Bekasi-Indonesia \\ 2. Program Studi DIII Teknologi Laboratorium Medik, STIKes Mitra Keluarga, Bekasi-Indonesia \\ *Korespondensi: Lili Rosmalia | STIKes Mitra Keluarga | lilirosmalia@gmail.com
}

\begin{abstract}
Abstrak
Pendahuluan: Cacing Ascaris lumbricoides salah satu cacing yang termasuk dalam cacing jenis Soil Transmitted Helminths (STH). Cacing A. lumbricoides hidup didalam usus halus manusia menyebabkan askariasis. Di Indonesia tahun 2006 prevalensi infeksi A. lumbricoides sebanyak 17,8\%. Tujuan penelitian mengetahui prevalensi anak yang terinfeksi telur A. lumbricoides di Yayasan Dinamika Indonesia, Bantar Gebang. Bantar Gebang sebagai tempat pembuangan sampah (TPS) menyebabkan sanitasi lingkungan yang buruk sehingga potensial terjadinya infeksi parasit usus.

Metode: Metode penelitian yang digunakan adalah deskriptif dengan desain cross sectional. Pemeriksaan telur A. lumbricoides dengan menggunakan metode natif dan metode apung dengan sentrifugasi. Responden penelitian yaitu anak-anak kelas 5 dan kelas 6 di Yayasan Dinamika Indonesia, Bantar Gebang.

Hasil: Hasil penelitian didapatkan jumlah anak yang terinfeksi telur A. lumbricoides 0\% dan jumlah anak yang terinfeksi larva cacing tambang sebanyak $1,9 \%$.

Kesimpulan: Tingkat infeksi A. lumbricoides di Yayasan Dinamika Indonesia, Bantar Gebang adalah negatif.

Kata Kunci: Ascaris lumbricoides, Infeksi, Bantar Gebang, Metode natif, Metode apung dengan sentrifugasi.
\end{abstract}

\section{Diterima 14 Oktober 2019; Accepted 30 Desember 2019}

\section{PENDAHULUAN}

Penyakit kecacingan adalah penyakit infeksi yang disebabkan oleh parasit cacing. Salah satu cacing yang dapat menyebabkan penyakit berasal dari golongan nematoda u. Nematoda usus terdapat 5 spesies yang penularannya melalui tanah atau biasa disebut dengan cacing Soil Transmitted Helminths (STH) (Margono, 2008). Cacing yang tergolong STH yaitu Ascaris lumbricoides, Trichuris trichiura, Necator americanus dan Ancylostoma sp. Menurut WHO tahun 2015 lebih dari 1,5 miliar orang atau 24\% populasi dunia terinfeksi STH (WHO, 2015). Infeksi yang paling banyak ditemukan yaitu infeksi cacing Ascaris lumbricoides. Infeksi yang disebabkan oleh cacing A. lumbricoides disebut askariasis. Prevalensi tertinggi didapatkan pada anak golongan usia sekolah dasar yaitu pada usia 7 - 12 tahun karena berhubungan dengan kebiasaan anak-anak yang sering bermain dengan tanah yang diduga terkontaminasi telur cacing (Mardiana \& Djarismawati, 2008).

Tingginya angka kejadian askariasis disebabkan oleh banyaknya telur yang dihasilkan oleh cacing betina A. lumbricoides yaitu berkisar $100.000-200.000$ telur dan disertai daya tahan telur cacing pada keadaan tanah yang kondusif dengan kelembaban tinggi dan suhu $25-30^{\circ} \mathrm{C}$ (Sutanto, Inge, et al., 2008). Di Indonesia tahun 2006 prevalensi infeksi Ascaris lumbricoides sebanyak 17,8\% (Depkes, 2006). Infeksi askariasis terjadi pada penduduk terutama yang tinggal di daerah pedesaan dengan status ekonomi yang kurang mampu yang mempengaruhi tingkat higienitas dan sanitasi lingkungan yang buruk (Sumanto, 2010)

Bantar Gebang merupakan sebuah kecamatan yang berada di kota Bekasi Provinsi Jawa Barat yang menjadi tempat pembuangan sampah dari seluruh wilayah Provinsi DKI Jakarta. Masalah lingkungan yang ditimbulkan dari pengolahan sampah adalah pencemaran air tanah oleh lindi yang merupakan cairan pekat yang berasal dari sampah dan sangat berbahaya bagi lingkungan dan manusia (Sulistyo, et al., 2013). Bantar Gebang sebagai tempat pembuangan sampah (TPS) memberikan dampak buruk yang dapat mempengaruhi kesehatan penduduk khususnya anak - anak. Hasil penelitian yang dilakukan di Bantar Gebang tahun 2014 menujukkan anak yang terinfeksi Ascaris lumbricoides sebanyak 5,4\% (Huda \& Winita, 2014). Penelitian ini dilakukan di Yayasan Dinamika Indonesia yang berlokasi di Ciketing Udik Bantar Gebang, Bekasi. Yayasan Dinamika Indonesia merupakan yayasan yang melakukan kegiatan kerjasama di bidang pendidikan dan sosial. khususnya bagi anak-anak pemulung yang bersekolah di Bantar 
Gebang. Sanitasi lingkungan yang buruk sangat potensial untuk terjadinya infeksi parasit usus. Oleh sebab itu, peneliti tertarik untuk mengetahui prevalensi infeksi parasit usus pada anak-anak di Bantar Gebang dengan pemeriksaan feses menggunakan metode natif dan metode apung dengan sentrifugasi. Metode natif adalah gold standart yang digunakan untuk mendeteksi adanya telur cacing dengan menggunakan laurtan $\mathrm{NaCL} 0,9 \%$, eosin atau lugol. Sedangkan metode apung dengan konsentrasi bekerja berdasarkan perbedaan massa jenis telur dan larutan (Soedarto, 2011).

\section{METODE}

Penelitian ini merupakan penelitian dengan metode deskriptif dengan desain cross-sectional. Subjek penelitian yaitu siswa kelas 5 dan kelas 6 di Yayasan Dinamika Indonesia, Bantar Gebang. Penelitian dilakukan pada 29 September - 10 Oktober 2017 di Yayasan Dinamika Indonesia, Bantar Gebang dan pemeriksaan dilakukan di Laboratorium Parasitologi STIKes Mitra Keluarga Bekasi. Total populasi dalam penelitian ini sebanyak 105 siswa. Sampel feses yang didapat sebanyak 53 yang memenuhi kriteria inklusi. Kriteria inklusi adalah siswa SD kelas 5 dan 6, laki-laki maupun perempuan, dan tidak mengonsumi obat cacing. Kriteria eksklusi adalah siswa kelas 5 dan 6 yang tidak bersedia diambil fesesnya dan tidak mengembalikan pot feses. Cara pengambilan data diawali dengan sosialisasi terlebih dahulu kepada siswa mengenai cara pengambilan feses, melakukan pengambilan sampel feses dengan pot steril yang diberi label, kemudian sampel feses diperiksa dengan menggunakan metode natif dan metode apung dengan sentrifugasi.

Alat yang digunakan dalam penelitian adalah pot steril, lidi, kaca preparat, kaca penutup preparat, alat setrifuse, tabung sentrifuse, kertas saring, label, pipet dan mikroskop. Bahan yang digunakan dalam penelitian adalah sampel feses, larutan NaCL $0,9 \%$, larutan eter dan akuades.

\section{HASIL}

Hasil pemeriksaan kecacingan adalah sebagai berikut:

Tabel 1. Frekuensi infeksi cacing Ascaris lumbricoides di Yayasan Dinamika Indonesia, Bantar Gebang.

\begin{tabular}{lcc}
\hline \multicolumn{1}{c}{ Hasil } & Frekuensi & Persen (\%) \\
\hline Positif & 0 & $0 \%$ \\
\hline Negatif & 53 & $100 \%$ \\
\hline
\end{tabular}

Berdasarkan tabel 1 didapatkan hasil pemeriksaan feses anak kelas 5 dan 6 di Yayasan Dinamika Indonesia menunjukan bahwa tidak ada anak yang terinfeksi telur Ascaris lumbricoides dengan hasil persentase $100 \%$ negatif dari 53 sampel yang diperiksa. Namun dari hasil pemeriksaan diperoleh hasil positif nonaskariasis.

Tabel 2. Frekuensi infeksi non Ascaris lumbricoides di Yayasan Dinamika Indonesia, Bantar Gebang.

\begin{tabular}{lcc}
\hline \multicolumn{1}{c}{ Hasil } & Frekuensi & Persen (\%) \\
\hline Positif & 1 & $1.9 \%$ \\
\hline Negatif & 52 & $98.1 \%$ \\
\hline
\end{tabular}

Berdasarkan tabel 2 didapatkan hasil pemeriksaan feses anak kelas 5 dan 6 di Yayasan Dinamika Indonesia menunjukan bahwa satu sampel positif larva cacing tambang dengan persentase sebesar 1,9\%.

\section{PEMBAHASAN}

Penelitian ini dilakukan pada anak-anak berusia dibawah 12 tahun karena pada usia tersebut memiliki resiko terkena infeksi parasit usus lebih tinggi yang potensial ditemukan Ascaris lumbricoides. Penularan infeksi askariasis terjadi melalui tanah. Anak memiliki kebiasaan bermain di tanah yang telah terkontaminasi telur cacing infektif menyebabkan anak lebih mudah terinfeksi askariasis (Mardiana \& Djarismawati, 2008). Kebiasaan tidak memotong kuku juga diduga kuat menjadi salah satu faktor resiko. 
Pada penelitian ini pemeriksaan feses dilakukan dengan metode natif dan metode apung dengan sentrifugasi tidak ditemukan telur Ascaris lumbricoides yang menandakan tidak ada anak yang terinfeksi askariasis. Angka tersebut lebih rendah dibandingkan dengan penelitian yang dilakukan tahun 2014 di Desa Sumur Batu, Bantar Gebang yang ditemukan infeksi askariasis sebesar 5,4\%. Perbedaan angka infeksi cacing dapat dipengaruhi beberapa faktor seperti lokasi penelitian, sanitasi lingkungan dan hagienitas perorangan (Huda \& Winita, 2014).

Dari 53 sampel feses yang diperiksa ditemukan 1 sampel terdapat larva cacing tambang pada metode pemeriksaan metode natif dengan persentase sebesar 1,9\%. Infeksi cacing tambang ditemukan pada penelitian ini berhubungan dengan lokasi penelitian yang kumuh. Menurut Inge (2008) sekitar 40\% anak yang tinggal di daerah kumuh terinfeksi cacing tambang. Menurut Noviastuti (2015) tanah yang yang gembur dan berpasir merupakan tempat yang sesuai untuk pertumbuhan larva cacing tambang sedangkan telur Ascaris lumbricoides berkembang dengan baik di tanah liat dengan kelembapan tinggi. Hal ini sesuai dengan lokasi penelitian yang memiliki kondisi tanah berpasir sehingga ditemukan larva cacing tambang. Hasil pemeriksaan feses anak kelas 5 dan 6 di Yayasan Dinamika Indonesia, Bantar Gebang dengan presentase $98.1 \%$ anak tidak terinfeksi kecacingan. Menurut Huda (2014) hal ini disebabkan oleh anak anak yang sudah memiliki kebiasaan buang air besar di WC, rajin memotong kuku, kondisi tanah yang berpasir dan memiliki lantai rumah berupa ubin/semen sehingga dapat memutus rantai penularan telur cacing. Yayasan Dinamika Indonesia memiliki fasilitas yang memadai yang didukung ruang kelas dengan lantai keramik/ubin dan memiliki toilet. Menurut penelitian Finka (2016) rendahnya kasus infeksi parasit usus ini diduga berkaitan dengan berbagai faktor seperti kesadaran masyarakat termasuk anak-anak mengenai sanitasi dan higienitas terhadap lingkungan, makanan dan minuman yang sudah baik. Menurut penelitian Dyah (2014) rendahnya angka infeksi cacing di Bantar Gebang disebabkan daerah yang dipenuhi oleh tumpukan sampah sehingga luas tanah yang merupakan tempat yang optimal untuk pematangan telur cacing menjadi sempit sehingga infeksi cacing menjadi lebih rendah.

\section{KESIMPULAN}

Berdasarkan hasil pemeriksaan telur Ascaris lumbricoides dengan metode natif dan metode apung dengan sentrifugasi di Yayasan Dinamika Indonesia, Bantar Gebang dapat disimpulkan sebagai berikut:

1. Prevalensi anak kelas 5 dan kelas 6 yang terinfeksi telur Ascaris lumbricoides adalah $0 \%$. Jenis parasit lain yang ditemukan adalah larva cacing Tambang sebesar 1,9\%.

2. Tingkat infeksi telur Ascaris lumbricoides pada anak kelas 5 dan 6 di Yayasan Dinamika Indonesia, Bantar Gebang adalah nol (negatif).

\section{REFERENSI}

Depkes, R., 2006. Profil Kesehatan Indonesia , Jakarta.

Dyah, A. P. \& Rawina, W., 2014. Prevalensi Infeksi Parasit Usus pada Anak-Anak di TPA Bantar Gebang dan Hubungannya dengan Sumber Air Konsumsi. Jakarta, FKUI.

Finka Tangel, Tuda, J. S. \& Pijoh, V. D., 2016. Infeksi parasit usus anak sekolah dasar di pesisir pantai Kecamatan Wori Kabupaten Minahasa Utara. jurnal e-Biomedik, Volume 4, pp. 70 - 75.

Huda, M. K. \& Winita, R., 2014. Angka Infeksi Parasit Usus dan Hubungannya dengan Jenis Pekerjaan pada Anak - anak di TPA BantarGebang, Bekasi, Jakarta: Universitas Indonesia.

Mardiana \& Djarismawati, 2008. Pravelensi Cacing Usus pada Murid Sekolah Dasar Wajib Belajar Pelayanan Gerakan Terpadu Pengentasan Kemiskinan Daerah Kumuh di Wilayah DKI Jakart. Jurnal Ekologi Kesehatan, 7(2).

Margono, S., 2008. Nematoda Usus Buku Ajar Parasitilogi Kedokteran. 4 ed. Jakarta: FK UI.

Noviastuti, A. R., 2015. Infeksi Soil Transimtted Helminths. Majority, 4(8), p. 110

Seodarto, 2011. Buku Ajar Parasitologi Kedokteran. Handbook Medical Parasitology. Sagung Seto. Jakarta.

Sulistyo, A. et al., 2013. Pengaruh Tempat Pengolahan Sampah Terpadu(TPST) Bantar Gebang Terhadap Penurunan Kualitas Lingkungan Sekitar. Jurnal Sumber Daya dan Lingkungan.

Sumanto, D., 2010. Faktor Risiko Infeksi Cacing Tambang Pada Anak Sekolah (Studi Kasus Kontrol di Desa Rejosari, Karangawen, Demak). Surabaya: Universitas Airlangga . 
Sutanto, Inge, Ismid, Sungkar, S. \& Sjariffudin, P. K., 2008. Buku Ajar Parasitologi Kedokteran. Jakarta: Fakultas Kedokterasn Universitas Indonesia.

WHO, 2015. Soil-transmitted helminth infections. [Online] Available at: http://www.who.int/mediacentre/factsheets/fs366/en/ [Accessed 25 September 2017]. 